\title{
ESCRITA DO PROFESSOR, CIDADANIA E IDENTIDADE
}

\author{
Maria José R. Faria Coracini *
}

\begin{abstract}
RESUMO: Este artigo discute a questão da cidadania, a partir da análise de textos redigidos por professores da rede estadual paulista, para um concurso denominado "O professor escreve sua história”, que nos permitiu estudar representaçōes recorrentes sobre cidadania e cidadão, que habitam o imaginário desses profissionais da educaçāo. Reflexões sobre a inserção social, ligada à cidadania constitui o objeto da segunda parte. Foi possível constatar que "cidadão", "cidadania" atrelados a "liberdade", "criticidade" constituem vocábulos, ao mesmo tempo, vazios e plenos de sentido: vazios, na medida em que parecem nada significar e plenos, na medida em que se apresentam como pacotes fechados de verdades naturalizadas e inquestionáveis. Esses mesmos pacotes não são desprovidos de conseqüências: carregam em si discriminações e preconceitos - escondidos e dissimulados - que minam nossa sociedade.
\end{abstract}

PAIAVRAS-CHAVE: discurso, identidade, subjetividade, inserção social, cidadania.

freqüente alusão e até mesmo referência explícita à for-
mação do cidadão nas redações de professores, como objetivo educacional, apontando para um discurso atual sobre a cidadania, recorrente no discurso político-educacional, levou-nos a investigar o assunto, em busca de respostas para perguntas que poderiam ser assim formuladas: O que significa ser cidadão e cida-

* Universidade Estadual de Campinas - Unicamp. Departamento de Lingüistica Aplicada. 
dão consciente ou melhor cidadão crítico? É possivel "ensinar" a ser cidadão? O que isso significa? Aliado a essas questões, encontra-se o tema bastante polêmico da inserção social, ou melhor dizendo da inclusão, questão que abordaremos a seguir.

Este trabalho se acha inserido no Projeto Interdiscurso e Identidade, apoiado pelo CNPq e pela FAPESP e se situa numa reflexão teórica em que se cruzam e se imbricam, ainda que de forma tensa e conflituosa, teorias do discurso e principios da desconstrução.

Para responder às perguntas acima formuladas, foram analisados redações de professores para um concurso proposto pelo Estado de São Paulo denominado O professor escreve a sua história, de que derivou um livro com o mesmo título, publicado pela FDE e Abrelivros, em 1996. A esse respeito, convém assinalar que, embora o tema proposto sugerisse uma auto-biografia, não havia nenhuma exigência quanto a isso; por essa razão, temos redações em primeira pessoa ou em terceira pessoa, relatando fatos supostamente da vida profissional de um(a) colega ou da vida de um(a) aluno(a) no contato com um(a) professor(a) que podia corresponder ou não ao sujeito enunciador. Sabendo que escrever em primeira pessoa não garante a fidelidade aos fatos - aliás, o que significa ser fiel aos fatos, se assumirmos o pressuposto de que os fatos são construções discursivas e, como tal, resultam da subjetividade interpretativa? - entendemos que seja qual for a forma lingüîstica, haverá sempre traços que apontam para a singularidade do sujeito enunciador que se revela no e pelo dizer, ainda que, conscientemente, creia apenas dizer.

Num primeiro momento, analisaremos alguns recortes de redações de professores que apontam para a presença do discurso da cidadania e para as representações que atravessam o imaginário desses profissionais a esse respeito, para, num segundo momento, trazer à baila a questão da cidadania como inserção social e democrática, bem como a questão tão atual da hospitalidade, cuja perspectiva política tem fortes repercussões na sociedade em geral e na escola em particular. 
Rev. ANPOLL, n. 17, p. 285-306, jul./dez. 2004.

\section{A questão da cidadania na escrita de professores}

S.1 Vou fazer uma poesia pra lá de moderna, Onde haja escola rimando com cidadania, professor rimando com respeito, aluno rimando com feliz. (p. 109) ${ }^{1}$

S.2 [nossa tarefa] é construir cidadãos críticos. (01938)

S.3 Assim, vou dedicando à causa da educação meus sonhos, labores, interesses, enquanto possa, no trabalho sagrado da sala de aula, berço da cidadania, onde a Pátria nasce, renasce e se fortalece a cada dia, nos bancos escolares. (01184)

Como é possível observar, esses excertos apontam para um antigo objetivo da escola que permanece na atualidade (formar, ou melhor, construir cidadãos e cidadãos críticos), ainda que não se saiba bem o que é ser cidadão e menos ainda cidadão crítico. Notese, no primeiro e no último recortes, a relação entre escola e cidadania ("...escola rimando com cidadania"; "...trabalho sagrado da sala de aula, berço da cidadania..."): a escola seria, assim, a responsável direta pela formação da cidadania e, portanto, do cidadão (aluno), espécie de refrão que se repete, ora de forma mais poética, ora menos, em muitas das redações analisadas, como é possível verificar nos recortes que se seguem.

Ainda em S.1, os pares lexicais professor - respeito, aluno feliz remetem à idéia de que cidadania, respeito e felicidade cami-

O número da página, que se encontra no final do excerto ou segmento (S), insere-o na obra O Professor escreve sua história, resultante do concurso de mesmo nome. Os excertos seguintes, seguidos do número de registro, foram retirados do acervo de redações que se apresentaram para o concurso. E importante deixar registrado que tivemos acesso a todas as redações, graças à Profa Marisa Lajolo que gentilmente cedeu, para fins de análise, essa parte de seu acervo ao nosso grupo de pesquisa. 
nham juntos, como conseqüência da tarefa "sagrada", portanto, intocável, divina ou até mesmo mágica da escola. Aliás, a remissão ao discurso religioso não pára por aí: no terceiro recorte, retorna a imagem de professor abnegado (missionário, cf. Coracini, 2003) que dedica toda a sua vida ("enquanto possa") à missão de educar e, portanto, de formar cidadãos. O professor entrega seus "sonhos, labores, interesses" à "causa da educação": observe-se a imagem de escola ou melhor de sala de aula, como o lugar onde "a Pátria nasce, renasce e se fortalece". Ligada à tarefa de construção da pátria, que se revela um tanto ufanista, se encontra, também no segundo recorte, a missão de construção da cidadania e do cidadão ao lado da idéia de que cabe ao professor, mais do que construir simples cidadãos, "construir cidadãos críticos". Em todos os casos, inclusive no segundo recorte, os enunciados pressupõem um consenso sobre o que seja cidadania, ser cidadão e crítico; tal consenso fecha as possibilidades (a meu ver, salutares) de questionamento das verdades subjacentes.

Vejamos mais um excerto:

S.4 Passo a passo, comigo, eles foram subindo degraus e de repente aqueles então "favelados" estavam tornando-se alunos" (p. 119).

Observe-se, nesse excerto, o efeito de sentido de "passo a passo, comigo, eles foram subindo degraus": o professor (na $1^{\text {a }}$ pessoa do singular, se apresenta como um pastor - aquele que, de posse da verdade, conduz o seu rebanho ao caminho ascendente (difícil porque é preciso galgar os (de)graus) em direção ao paraíso, ou ao menos, a um lugar mais alto (metáfora conceitual, no dizer de Lakoff \& Johnson, 1980). Sem ele, não seria possivel avançar e, muito menos, chegar ao topo... E, "de repente", quase que por um efeito de magia, de milagre, "o favelado se transforma em aluno" (ou em gente?). Atente-se para a oposição favelado/aluno e para o efeito de sentido da locução adverbial "de repente": se, na primeira parte de 
Rev. ANPOLL, n. 17, p. 285-306, jul./dez. 2004.

S.4, o professor parece estar no controle da situação educativa, já que conhece o caminho a ser percorrido pelo aluno (por isso o acompanha), na segunda parte, revela-se a impossibilidade de controle, a imprevisibilidade do ato educativo: o favelado torna-se aluno quando? como? Não é possivel saber...

Imbricado nessa idéia de progresso ${ }^{2}$, ao mesmo tempo controlado e descontrolado, emerge, pelas brechas da linguagem (porosa no dizer de Authier-Revuz, 1998), um ato falho, denunciando uma discriminação social, certamente inconsciente, naturalizada pelo pré-conceito que habita a sociedade brasileira; apenas o uso de aspas na palavra favelado pode indiciar uma certa consciência da parte do sujeito enunciador e, talvez, o desejo de que não se entenda favelado em oposição a aluno ou a gente (aspas como marca da heterogeneidade, ou seja, do atravessamento de outras vozes, cf. Authier-Revuz, 1998). Seja lá como for, o "favelado" estava longe de ser um cidadão; foi preciso transformá-lo em aluno para que pudesse se tornar um cidadão.

Ainda com relação ao poder de transformação da educação e, como decorrência, do professor, vejamos S. 5:

S.5 Refleti sobre o PODER DE TRANSFORMAÇÃO que o professor possui. Não metal em ouro, como queriam os alquimistas, mas no poder de transformar um ser vazio em um homem pleno de conhecimentos, capaz de entender, criticar e mudar a sua realidade" (p. 106)

Também neste recorte, emergem fragmentos ou fagulhas de discriminação que, certamente, não é consciente, mas que é denunciada pela denegação: "não [transformar] metal em ouro", o que pressupõe: sim, transformar metal, material de pouco valor, em ouro, material valioso..., cujo efeito de sentido não é amenizado, como poderia fazer crer a ordem dos argumentos, pelo que segue,

2 A esse respeito, ler Mascia, 2001. 
precedido da conjunção "mas"; pelo contrário, em vez de uma oposição, o articulador argumentativo "mas" introduz um reforço ou a afirmação desse efeito de sentido. Afinal, "transformar um ser vazio em um homem pleno de conhecimentos" (observe-se a oposição ser (ao mesmo tempo substantivo e verbo)-vazio (de conhecimentos) / homem-pleno (de conhecimentos), é o mesmo que transformar metal em ouro... Note-se que S.5 aponta para a onipotência do criador (professor) em oposição à fragilidade da criatura (aluno) que não era nada ("vazio"), antes de existir, ou melhor, que não existia - como cidadão, como gente? - antes da transformação em "homem pleno de conhecimentos, capaz de entender, criticar e mudar a sua realidade"; isto é, foi preciso que o professor o transformasse em alguém semelhante a ele (como Deus que criou o homem à sua imagem e semelhança), para que ele pudesse atingir o direito à cidadania (ver, mais adiante, a definição de cidadão do dicionário). Neste caso, ser cidadão parece significar ser "capaz de entender, criticar e mudar a sua realidade"...

De forma mais explícita, os recortes (S. 6 e S. 7) apontam para a função da escola de "formar cidadãos conscientes". Senão vejamos:

S.6 /.../ Os olhos vencem a teima e ele vai dormir. Consegue? Custa a conseguir, pois agora a teimosia dos olhos cede lugar à do cérebro que the repete sem parar: "é preciso reciclar-se, repensar a educação, mudar as estratégias didáticas; estamos entrando no terceiro milênio; estamos na era da informática e da globalização; devemos formar leitores críticos; formar cidadãos conscientes para o livre exercicio da democracia..."

S.7 Sempre acreditei que a criança é um ser moldável ao que se pretende trabalhar, educar, enfim, formar-se cidadão crítico, consiste basicamente na definição consciente de tais objetivos (sic). 
Rev. ANPOLL, n. 17, p. 285-306, jul./dez. 2004.

Retorna à baila, em S.7, comentário de um professor sobre sua tarefa de ensinar, a idéia de que ele é imprescindível para a formação do aluno, que, por ser criança, é como uma massa disforme a ser "moldada" pelas e nas mãos do professor que, intencional e, portanto, conscientemente, assume a tarefa de (trans)formá-lo em "cidadão crítico": para isso, basta ter objetivos claros, conscientes...

Observe-se, em S.6, além da ênfase na tarefa de (trans)formação, a necessidade de adequação do ensino, da educação ao momento histórico-social em que se vive: tempo das novas tecnologias ("informática") e da "globalização". A posição central que ocupa essa parte do enunciado o faz funcionar como um eixo causal que une o que precede ao que sucede: é porque estamos entrando no terceiro milênio, na era da informática e da globalização que precisamos repensar a educação, mudar as estratégias didáticas; é por essa mesma razão que é preciso formar leitores críticos-cidadãos conscientes-livre exercício da democracia. Aqui, também, o ponto e vírgula (cf. S.6) funciona como um elo que une e desune os enunciados, numa relação em cadeia de causa e conseqüência: formar leitores críticos tem como conseqüência a formação de cidadãos conscientes que, por sua vez, implica no "livre exercício da democracia". Observe-se que, neste caso, um segmento funciona como definição do outro, numa reversibilidade total: assim, ser leitor crítico é ser cidadão consciente (e vice-versa) e exercer livremente a democracia é ser um cidadão consciente (e vice-versa).

Ainda assim, o que se percebe é uma repetição redundante de termos que parecem esvaziados de sentido ou tão plenos de sentido - naturalizado pela ideologia dominante - que não precisam de explicitação: o que é de fato ser crítico (leitor e cidadão)? O que significa e, sobretudo, em que implica o "livre exercício da democracia"? O que é democracia? Vivemos, de fato e de direito, num regime democrático (demo=povo)? O mesmo vazio é percebido em S.8 e S. 9: 
S. 8 (...) a sociedade que as recebe não é capaz de moldálos aos princípios de cidadão, não os forma, apenas os mantém sem identidade. (02028)

S.9 [Na redação é importante] o senso crítico, porque o objetivo de minha disciplina é criar cidadãos críticos que transformem a realidade com criatividade.

Ao retomar a idéia de que, sem a escola, a criança ou o jovem (ou o adulto) não teria identidade, S. 8 atribui ao professor a tarefa de moldar o aluno, emoldurá-lo(a), modelá-lo(a), enfim, construir (para ele e com ele) uma identidade. A voz que desvaloriza a escola, concedendo à sociedade a tarefa de moldar a criança aos "princípios de cidadão" vê-se apagada pelo enunciador que a nega na defesa da valorização da escola e de si mesmo como profissional (que, ao mesmo tempo, denuncia vozes que o desvalorizam ${ }^{3}$ ), imprescindível para a construção da identidade do cidadão. Mais uma vez, naturaliza-se a noção de cidadania e, com ela, a noção de identidade que habita o sujeito-professor de tal modo que, mesmo numa resposta a uma pergunta que pretende saber o que lhe parece importante numa redação (cf. S.9), um professor aponta o senso crítico (mais uma vez, um todo fechado em e sobre si mesmo) e o justifica pelo objetivo da disciplina sob sua responsabilidade: "criar cidadãos críticos que transformem a realidade com criatividade". Criar, criticar, criatividade parecem se unir por uma raiz que ressoa na constituição interna dos vocábulos, (cri-ar, grito, ar...) concedendo ao professor o lugar central de exemplo, de ponto de partida e de chegada: afinal, quem cria é o professor que faz nascer, com seu grito, o aluno crítico, que, por ser crítico, passa também a exercer a atividade de criar ou de criar atividade (criatividade), retornando ou assumindo a posição de criador, numa corrente dolorosa e prazeirosa, que torna permanente o que é provisório, eterno o que

3 A esse respeito, ler Lima (2001). 
Rev. ANPOLL, n. 17, p. 285-306, jul./dez. 2004.

é mortal: não é esse o desejo que constitui o sujeito da falta, o sujeito que, sabendo-se mortal, incompleto, castrado, anseia pela completude, pela permanência, pela eternidade?

Cabe, ainda, para terminar esta parte, observar que não é à toa que, a todo momento, emerge no discurso do professor, de forma ora mais ora menos explícita, a questão da cidadania, como um pacote fechado, fetichizado, onde apenas se vislumbram alguns ingredientes: criticidade, democracia, liberdade, criatividade..., norteadores de uma prática didática que também se apresenta como um fetiche, pacote fechado, que se quer transformador e criador, silenciando as vozes sociais que questinam e desvalorizam a escola e o professor.

Todos esses efeitos de sentido de um discurso que se apresenta vazio e pleno ao mesmo tempo encontram sua justificativa no discurso político-educacional, aqui representado pelos Parâmetros Curriculares Nacionais (PCNs) que dedicam uma seção inteira à questão da cidadania, na busca de definir ou, ao menos, de defender a necessidade da formação do cidadão brasileiro, como uma tarefa democrática da escola, inserida no mundo globalizado. Aliás, como vimos, esse cunho político ecoa em S.6, trazido à memória pelo termo "democracia", embora numa expressão que soa como um lugar comum - "livre exercício da democracia" (repetição marcada inclusive pela ordem dos vocábulos).

Vejamos um recorte dessa seção:

(...) é cada vez mais forte o reconhecimento de que as diversidades étnicas, regionais e culturais continuam a exercer um papel crucial e de que é no âmbito do Estado/Nação que a cidadania pode ser exercida.

O exercício da cidadania numa sociedade democrática, por sua vez, pressupõe a participação política de todos na definição de rumos que serão assumidos pela nação. As formas de participação política se expressam não só na escolha de representantes políticos e governantes, mas também na participação em movimentos sociais, no envolvimento com temas e questões da nação e em todos os niveis da vida cotidiana. 


\section{(...) (PCN - Terceiro e Quarto Ciclos do Ensino Fundamental, Introdução, p. 5)}

É interessante observar que os PCNs trazem à baila a questão da diversidade, da cidadania como participação política "de todos" na definição dos rumos da nação, postulando tal participação como decorrência natural do regime democrático. O tom assertivo e informativo do documento (manifestado pelo uso dos verbos no indicativo presente ou futuro, pelo uso de orações completas - com sujeito, verbo e complemento -, estrutura fechada que controla, ainda que ilusoriamente, o sentido) produz o efeito de verdade inquestionável, objetiva e definitiva, silenciando ou apagando a discriminação que impera na sociedade brasileira tanto nas situações de "escolha de representantes políticos e governantes" quanto na "participação em movimentos sociais...". Essa tendência de tornar natural o que é construção social, de naturalizar o que existe apenas na teoria como se a sua prática ou a sua aplicação dependesse apenas do povo - que, afinal de contas, deveria ser o auto-gestor num governo que se diz "demo-crático" (não demônio, mas povo) constitui uma das características da ideologia neoliberal segundo a qual todos têm oportunidades iguais (todos são iguais perante a lei...); como edecorrência, o sucesso ou o insucesso é da inteira responsabilidade de cada indivíduo.

Igualdade e tolerância que presenciamos e ouvimos na teoria, mas cujos efeitos práticos são bem diferentes! Basta observar o discurso de professores do ensino fundamental e médio (ver excertos analisados) que passaram pela escola, muitos até pela universidade, e que repetem ad nauseam termos esvaziados pela moda, pelos especialistas, pela "ordem do dia" que constitui o seu imaginário e que, não raro, se chocam com o Real, inacessível a não ser pela linguagem que permite, pelas brechas do dizer, a emergência de discriminações e pré-conceitos, como foi possível vislumbrar em S.4 e S.5, e, de forma mais opaca, nos demais exemplos aqui trazidos. 
Rev. ANPOLL, n. 17, p. 285-306, jul./dez. 2004.

\section{Cidadania e inclusão social}

Os PCNs e alguns excertos de redações de professores relacionam, com razão, cidadania e Estado: o exercício da cidadania depende, sem dúvida, do Estado e das leis que regem a Nação: ser cidadão é estar no exercício de seus plenos direitos políticos, como mostra muito bem a definição encontrada nos verbetes "cidadania e "cidadão", no dicionário Aurélio:

Cidadania: qualidade ou estado de cidadão: cidadão brasileiro.

Cidadão: 1. indivíduo no gozo dos direitos civis e políticos de um Estado, ou no desempenho de seus deveres para com este. 2. habitante da cidade. 3. Pop. Indivíduo, homem, sujeito (...) Cidadão do mundo. Homem que põe os interesses da humanidade acima dos da pátria; cidadão do Universo.

Na verdade, como foi possivel detectar na análise dos recortes de redações de professores, o uso desses termos está banalizado assim como parece banalizado falar de direitos e deveres para com o Estado, como se este fosse uma entidade independente e soberana, acima da sociedade. Ora, o dicionário confere cidadania ao habitante da cidade - em oposição ao camponês (habitante do campo)? - vocábulo que certamente remete à Cidade ideal de que falava Aristóteles. Mas, logo a seguir, traz a acepção popular de individuo, sujeito, homem, esvaziando-o de todo e qualquer sentido político. O efeito de neutralidade do dicionário não impede que se perceba que a cidadania não é atributo de todos, contrariamente ao discurso dos PCNs, atravessado pelo discurso jurídico: aquele que não se identifica com "indivíduo no gozo dos direitos civis e políticos" não pode se considerar cidadão... e sabemos que muitos brasileiros encontram-se, de fato, à margem da cidadania, porque não "gozam" de seus "direitos civis e políticos". 
Estariam em seus direitos civis os habitantes da cidade, sem terra e sem teto? Estariam no exercício de seus direitos civis os habitantes do sertão nordestino, os analfabetos ou analfabetos funcionais? Seriam considerados cidadãos os habitantes de favelas que invadem a periferia - e os centros - das grandes cidades, e, conseqüentemente, as escolas públicas? A estes são concedidos apenas deveres, mas como exigir deles o respeito à ordem dominante, se não têm direitos, se, para sobreviverem, precisaram construir outro mundo, outra ordem, outras regras, outras leis, outra ética? Quem assistiu ao filme "Cidade de Deus" sabe que estou me referindo à impossibilidade de uma compreensão mútua entre habitantes que convivem lado a lado, mas que pertencem a sociedades radicalmente distintas em que a tolerância, que só existe na teoria, acontece apenas num dos lados, naquele que se acredita dominante, mas que se extasia diante da perda de controle da ordem vigente, daquele que acredita ter a verdade, mas se surpreende com a impossibilidade de transmiti-la, daquele que esquece que permitiu que uma sociedade paralela fosse construída, porque na sua, os outros, esses outros não tinham lugar (violência que gerou violência) ...

Com relação à última acepção do dicionário, cidadão do mundo é aquele que "coloca os interesses da humanidade acima dos interesses da pátria”, da sociedade em que vive. Quem seria, então, cidadão do mundo? Certamente, aquele que assim se crê. No mundo capitalista dominado pela ideologia neoliberal, onde o capital é o bem maior da humanidade, porque decorre das bêncãos divinas de um Deus que recompensa aquele que trabalha e produz, o povo americano tem (ou se dá) o direito de se acreditar cidadão do mundo, salvador da humanidade, da liberdade e da democracia. Essa crença ou esse poder lhe dá também o direito de atribuir ao outro - diferente, com outras crenças - o epiteto de terroristas e, sobretudo, the dá o direito de se sentir vítima da incompreensão daqueles que não reconhecem a sua bondade, a sua tolerância, a sua magnitude... Todos sabemos que o ataque de 11 de setembro funcionou, metonimicamente - porque não promo- 
Rev. ANPOLL, n. 17, p. 285-306, jul./dez. 2004.

veu nenhum deslocamento efetivo, nenhum auto-questionamento -, no sentido de reforçar ainda mais os esquemas de proteção, afrouxados pela certeza de que eram inatacáveis, intocáveis, inquestionáveis... Mas essas estratégias acabam por denunciar a inefabilidade, a impossibilidade de tudo controlar, a falta que constitui o sujeito e, com maior força, uma nação.

Como já foi dito, para ser considerado cidadão, o indivíduo precisa entrar nas regras do jogo hegemônico, ou seja, nas regras do jogo do poder e, nele, dentro dele, encontrar o seu lugar. Fictícia ou ilusoriamente, acreditamos que, num Estado democrático, todos têm a possibilidade de se tornarem cidadãos: basta ir à escola e se conscientizar de seus direitos politicos - que, na verdade, para uns (maioria no Brasil) não passam de deveres (afinal, no momento de votar, todos são promovidos a cidadãos: basta saber assinar seu nome e fazer uma cruz - ao lado do nome de um político "indicado" - por mão própria ou por sistema eletrônico), mas quanto aos direitos civis o caso muda de figura...

Participei, há alguns meses atrás, de um congresso de Literatura cujo título era Vozes do Terceiro Milênio: a arte da inclusão. Um dos temas abordados em todas as mesas ligava a inclusão à questão da cidadania. Assim, a cidadania, no Terceiro Milênio, pressupõe inclusão: só é cidadão aquele que se sentir incluído. Assim, trazer para dentro o que está fora, o que se encontra à margem da sociedade deve ser uma das tarefas da escola, da universidade, da sociedade... Ora, o que vem a ser isso? Nesse encontro, as diferentes conferências e comunicações orientaram a nossa interpretação para a consideração da abertura de espaço ao outro, diferente (social e/ou fisicamente), permitindo que outros, menos favorecidos pela natureza ou pela sorte, com defeitos físicos, por exemplo, ocupem assento ao lado daqueles que são considerados "normais". Ficou muito claro para mim que incluir o diferente significa permitir que o outro conheça as nossas verdades - as verdades dos "normais" - o mundo "perfeito" ou perfectivel 
dos perfeitos (normais), na expectativa, ainda que não explicitada e certamente inconsciente, de que venham a se tornar semelhantes a nós ou talvez de que se mantenham diferentes de nós para que nos sintamos mais felizes, mais privilegiados do que eles e, conseqüentemente, menos limitados do que somos (ainda que não o admitamos conscientemente).

Ser tolerante e generoso é uma espécie de slogan que está na ordem do dia. Mas, para que a uns sejam atribuídas essas qualidades, não será preciso que outros se mantenham onde estão, isto é, numa posição de inferioridade, de submissão, de necessidade? Várias vezes ouvi na minha juventude da boca de cristãos "generosos" e conscientes: "felizmente, há pobres; assim, podemos exercer a nossa bondade e dar a eles o que não têm"... Poderíamos acrescentar, no mesmo tom de hipocrisia social: "felizmente existem aqueles que não vêem, não ouvem, não andam... assim, podemos exercitar nossa tolerância ${ }^{4}$, dar-lhes nossa ajuda, colocando-os ao nosso lado, e assim procedendo nos sentir confortados pela saúde de nossos membros, pela perfeição de nossos sentidos...".

Essa situação crua, nua, cruel, não estaria sendo, evidentemente na melhor das intenções, fomentada pelo Ministério da Educação em obediência a uma lei que obriga a conceder vagas na universidade para egressos da escola pública, para negros e para aqueles que não gozam de "normalidade": surdos, cegos, paraplégicos... Todos eles devem ter lugar numa sala de aula "normal”, partilhar do mesmo espaço físico, um ao lado do outro, como se isso significasse, por si só e por força da lei, ausência de discriminação, in-clusão, in-serção social.

4 Zizek, na conferência proferida na Universidade de São Paulo, em 10 de dezembro de 2003, por ocasião do lançamento de sua obra Bem-vindo ao deserto do Real!, traduzida para o português, referiu-se mais ou menos assim a esse espirito de tolerância tão comum nos dias de hoje: "tolero você para que você fique longe de mim, para manter a diferença, para que sejamos cada vez mais diferentes". Aliás, se eu tolero é porque não amo, não suporto, não gosto... 
Rev. ANPOLL, n. 17, p. 285-306, jul./dez. 2004.

Ora, sabe-se muito bem que esse apagamento de fronteiras do diferente, daquele que exibe falhas, que justamente por exibilas me agride (já que me reconheço nele, identifico-me inconscientemente com ele, vejo e sinto meus defeitos, minhas falhas, escancaradas no outro que aceito mas rejeito, que tolero, justamente porque me incomoda, porque não consigo amá-lo em mim). $\mathrm{Na}$ verdade, poderíamos chamar a esse comportamento social de "experiências de estar junto" ou de "ficar" junto(s); aliás, num mundo em que dominam as aparências, são cada vez mais freqüentes essas experiências que não estabelecem nenhum compromisso, nenhum laço social: "ficar" parece caracterizar a atitude de um outro tipo de subjetividade que está proliferando nas várias sociedades, como resultado do capitalismo feroz do Ocidente. dominado pela mercadoria, pela objetificação de tudo e de todos. Assim, não raras são as ocasiões em que jovens, estimulados pela internet (salas de bate-papo) são instados a se reunirem num evento comum, como por exemplo, comparecer a um certo lugar marcado e todos juntos, baterem os pés durante 10 minutos sem saberem por que ou para que, e, assim, se divertirem e "gozarem" no não sentido de um ato sem maiores conseqüências, ao menos aparentemente... É mais ou menos assim que Melman (2002) se refere ao sujeito das pulsões, movido apenas pelo imaginário, para quem tudo é possivel porque não se reconhece castrado.

Nessa linha de raciocínio ou de ausência de racionalidade, (a)juntar individuos pode, não apenas colaborar para a in-serção social ou seja, para a aceitação das diferenças, para a promoção da sociabilidade e da integração de todos, como parece ser o propósito da lei (acreditando que não seja apenas fruto da demagogia de políticos interessados em angariar votos para as próximas eleições), mas, ao mesmo tempo, constituir uma ótima maneira de reforçar as diferenças: o professor não sabe o que fazer com essas crianças ou esses jovens; o colega não sabe como se comunicar com ele ou ela; este ou esta acaba por se sentir incapaz por não conseguir 
Coracini, Maria José R. Faria. Escrita do Professor, Cidadania e Identidade.

fazer o que o outro faz, não conseguir ser o que e como o outro é, esse outro que ele ou ela deseja, mas que lhe é inatingivel, o desejo, em suma, de ser o desejo do outro...

Participei durante 6 meses das atividades de uma clínica particular de surdos-mudos, há anos atrás, na cidade de São Paulo. Lá, as crianças eram encaminhadas pelas mães para receberem reforço escolar, porque estavam em classes normais na escola para todos. Aqueles que apresentavam maiores dificuldades tinham seções particulares com uma fonoaudióloga que os fazia ler em voz alta um texto do livro didático adotado na escola que eles freqüentavam. Eram crianças que estavam aprendendo a chamada leitura labial e, com a ajuda de aparelhos de audição, estavam sendo "treinadas" para "falar" como os "normais" falam. E obviamente tinham dificuldade em ler: ficavam nervosos, angustiados até; paravam de ler, muitas vezes desistiam, se desesperavam, parecendo agressivos e arredios, porque, com certeza, nada daquilo fazia sentido - nem o texto, nem a atividade e muito menos, a leitura labial. Os pais e os fonoaudiólogos insistiam em transformálos em "normais", em ouvintes... em mostrar a eles o mundo são dos sadios, o mundo ideal dos perfeitos ao qual essas criaturas não poderiam pertencer a não ser de forma artificial ou pelo desejo (frustrado) de aceder ao inacessivel; e, assim, procedendo, embora inconscientemente, não pareciam ter o mínimo respeito pela diferença. Neste caso, o diferente parece ser sinônimo de inferioridade, de incompetência, de desigualdade.

Felizmente, hoje, a orientação parece ser outra com a aprovação da linguagem de sinais pelo Senado, embora não tenha desaparecido completamente da sociedade a vontade de igualar, de homogeneizar na melhor das intenções... e, assim, promover a desigualdade, pois, contraditoriamente, no exato momento em que se deseja conceder espaço (observe-se o uso, nem sempre intencional, de verbos como conceder, permitir, abrir) é que se cava um abismo ainda maior entre uns e outros, constroem-se muros que separam, 
Rev. ANPOLL, n. 17, p. 285-306, jul./dez. 2004.

que distinguem uns e outros, reforçam-se as diferenças. É exatamente quando pensamos tornar iguais os desiguais que nos damos conta da impossibilidade da igualdade e reforçamos a desigualdade e a discriminação. O mesmo ocorre com os economicamente desfavorecidos, como vimos em S. 4, em que se explicita o desejo de transformar favelados em alunos, isto é, semelhantes a nós letrados, mas apenas na aparência, porque serão muito provavelmente discriminados, ocuparão, certamente, lugares menos valorizados, para que outros, como nós, possam continuar ocupando os melhores lugares na sociedade... Não quero entrar na questão racial, mas acredito que a situação seja semelhante: os negros terão assentos nas universidades públicas não porque têm competência, não porque são iguais aos brancos, não porque são tão inteligentes ou mais do que os outros, não porque têm os mesmos direitos e, portanto, podem exigir as mesmas oportunidades que os brancos, não porque são tão cidadãos quanto aqueles, mas porque estes são generosos, tolerantes, bondosos...

Será isso cidadania? Será isso saber viver na diferença, na diversidade - étnica, regional e cultural? Derrida aborda a questão da hospitalidade como uma forma de inserção social do estrangeiro - afinal, não é preciso ter nascido no Brasil para ser considerado cidadão brasileiro (sabemos que o índio nasceu no Brasil e nem por isso é naturalmente cidadão brasileiro). Derrida (1997b), referindose aos imigrantes, estrangeiros na terra que os colhe, recolhe e rejeita, diz o seguinte:

Hoje uma reflexão sobre a hospitalidade supõe, dentre outras coisas, a possibilidade de uma delimitação rigorosa dos patamares ou das fronteiras: entre o familiar e o não familiar, entre o estrangeiro e o não estrangero, o cidadão e o não cidadão, mas primeiramente entre o privado e o público, o direito privado e o direito público etc. (p. 45) ${ }^{5}$

5 Tradução minha. 
Mais adiante, Derrida denuncia a finitude e a provisoriedade da hospitalidade que serve aos interesses momentâneos daqueles que têm poder, que estão no poder, no desejo de propor ou de sonhar com a utopia de uma hospitalidade universal, incondicional, sem reservas, sem limites, sem fronteiras, em que o estrangeiro não seja tomado como "um fora da lei na lei", isto é, ao mesmo tempo inserido e excluído na sociedade que o acolhe e o rejeita (p.75-6). Num outro texto (1997 a), Derrida termina sonhando com a construção de cidades-refúgios, resposta imediata, "mais justa do que o direito existente", ao crime, à violência, à perseguição... dos estrangeiros pelas autoridades constituídas:

Essa experiência das cidades-refúgios, eu a imagino também como o que dá lugar, um lugar de pensamento, e é ainda o asilo ou a hospitalidade, à experimentação de um direito e de uma democracia por vir. No patamar [seuil] dessas cidades, dessas novas cidades que não seriam o mesmo que "cidades novas", uma certa idéia do cosmopolitismo, uma outra, talvez ainda não tenha chegado

- Sim, chegou...

— ...então, talvez não a tenhamos reconhecido. (p.58) ${ }^{6}$

Diálogo fictício que aponta para uma utopia ou para a esperança de um mundo mais justo, onde todos tenham de fato os mesmos direitos, esperança numa democracia que ainda não existe, num mundo por vir... Mas, retornemos, sem a termos abandonado, à questão que motivou este texto: a cidadania, a identidade e a inserção social. Tanto como os que vêm de outros países, de outras culturas, de outras linguas, o "favelado", o cego, o surdo... são estrangeiros que, (i)migram para um mundo que não é o seu, sofrem o estranhamento nesse mundo e desse mundo, incomodando, perturbando os "normais" tanto quanto os estrangeiros incomodam, perturbam os "nativos" ou os "normais", já que, como afirma Derrida

6 Tradução minha. 
Rev. ANPOLL, n. 17, p. 285-306, jul./dez. 2004.

(1997 b: 11), o estrangeiro "é aquele que, fazendo a primeira pergunta, me põe em questão”, me questiona, questiona meus valores, meus hábitos, minhas crenças; e porque me questiona me perturba... Por isso mesmo, por causa da violência que vem da pulsão de vida, e que constitui o homem (Freud, 1997), foi preciso criar leis, regras, direitos, o direito à hospitalidade, que, no movimento de assegurá-la, acirra a diferença e a separação.

$\hat{\mathrm{E}}$ esta concepção de cidadania que quero aqui defender: a cidadania como hospitalidade, como direito de ser o que se é, de dizer e, ao dizer, se dizer à sua maneira, com suas especificidades, com sua singularidade. Para isso, é preciso ouvir - à maneira da escuta psicanalítica -, calar-se, para que o outro fale e, assim, compreender o outro mundo, o mundo do outro, diferente do nosso, nele penetrar para nos transformar e não apenas transformar o outro, fazendo-o vir até nós; é preciso abrirmo-nos para o outro e não apenas abrirmos o nosso mundo para que esse outro nele busque um lugar que não encontra e conheça as maravilhas que temos e somos e às quais jamais terá acesso... Por que não permitir que nos digam as "suas" maravilhas, as "suas" crenças, as "suas" verdades, tão verdadeiras como as nossas verdades, tão ilusórias como as nossas ilusões...?

No congresso que mencionei há pouco, apenas um participante de uma mesa-redonda parece ter entendido a inserção social da maneira como eu acredito ser a única que promove o outro e não apenas a si próprio: um índio, que disse no "seu" português que, pela primeira vez, ele tinha sido chamado para falar, falar de sua comunidade, de como eles se sentem, falar de sua cultura, de suas crenças, não como seres exóticos, não como curiosidades, que atraem turistas e curiosos, não como alguém que vinha pedir algo, mas como representante de um povo que tem suas caracteristicas e que pretende defendê-las; era ao menos dessa maneira que ele havia recebido o convite para participar daquele evento, ao lado de um escritor negro, de um intelectual de renome e de uma lingüísta anã. 


\section{Alinhavando...}

A esta altura, o leitor deve estar se perguntando: mas o que tem tudo isso a ver com a escrita do professor e com a identidade, parte do título deste texto? Ora, a escrita, que aqui vou tomar como escritura, já que não se limita ao ato mecânico de escrever, não significa repetir sem digerir, repetir sem (quase) nada acrescentar, mas significa criar, exteriorizar o que está dentro, na simbiose com o fora, que constitui o sujeito; exteriorizar o que foi digerido, deixando aí marcas da singularidade, inscrições que poderão ser lidas, apre(en)didas por si e/ou por outro numa rede interminável de identificações subjetivas. Assim, se a palavra passa pelo sujeito (sujeito da linguagem), o atravessa, faz corpo, o constitui, este, arremedando Lacan, mais se diz do que diz, mais se apresenta do que apresenta ou informa.

Mas, para que isso possa acontecer, é preciso que se reveja a concepção de cidadania, que se repense a escola, não a partir de modelos, receitas, fôrmas, mas a partir do outro que sou eu e do eu que sou outro, não impossibilitando essa expressão, não reduzindo tudo e todos a regras, a formas, a forrmas, a modelos..., mas se abrindo para acolher, hospedar o diferente, aprendendo com ele e dando-se a ele. E nesse movimento heterogêneo em direção ao e do outro, transformam-se um e outro, formam-se laços, cadeias, tecem-se redes, tecidos, órgãos, apagam-se as dicotomias, as fronteiras, os abismos intransponiveis...

Utopia? Muito provavelmente, mas só assim, acredito eu, será possível falar de cidadania, de hospitalidade, de acolhida do estranho-estrangeiro-outro-hóspede-hostil, de configurações identitárias diferentes, que questionam verdades pré-estabelecidas e desestabilizam nossa identidade, sentimento ilusório de unidade, de ser completo e inteiro, mostrando-a como ela é: em movimento, fragmentada, híbrida, constituída pelo outro, por todos os outros com quem criamos laços e que vão nos modificando no percurso da vida... 
Rev. ANPOLL, n. 17, p. 285-306, jul./dez. 2004.

RÉSUMÉ: Cet article a pour but de discuter la question de la citoyenneté, à partir de l'analyse de textes rédigés par des instituteurs de l'école publique de l'Etat de São Paulo, dans un concours nommé "L'instituteur écrit son histoire", qui nous a permis d'étudier des représentations de citoyen et de citoyenneté qui habitent l'imaginaire de ces professionnels en éducation. Des réflexions sur l'insertion sociale liée à la citoyenneté a fait l'objet de la seconde partie. On a pu constater que "citoyen", citoyenneté" liés à "liberté", "criticité" constituent des vocables, en même temps, vides et pleins de sens: vides dans la mesure où ne veulent rien dire et pleins de sens parce qu'ils se présentent comme des "paquets" fermés, des vérités naturalisées, qui les rendent inquestionables et objectifs. Ces mêmes paquets ne sont pas sans conséquences: ils sont porteurs de discriminations et de préjugés - cachés et dissimulés - qui minent notre société.

MOTS-CLE: discours; identité; subjectivité; insertion sociale; citoyenneté.

\section{BIBLIOGRAFIA}

Authier-Revuz, J. (1998) Palauras Incertas - as não coincidências do dizer. Campinas: Editora da Unicamp.

Coracini, M.J.R.F. (2003) Subjetividade e Identidade do(a) professor(a) de português (LM). In CORACINI, M.J. (org.) Identidade e Discurso: (des)construindo subjetividades. Campinas / Chapecó: Editora da Unicamp / Editora Argos, pp. 239-255.

Derrida, J. (1997a) Cosmopolites de tous les pays, encore un effort! $\mathrm{Pa}-$ ris: Galilée.

Derrida, J. (1997b) De l'Hospitalité. Paris: Calman-Lévy.

Freud, S. (1997) O Mal-estar na civilização. Trad. José Octavio de Aguiar Abreu. Rio de Janeiro: Imago.

LAKoff, G. \& M. JOHNSON (1980) Metaphors we live by. London: University of Chicago Press.

MAsciA, M. A. A. (2001) Investigações discursivas na pós-modernidade: uma análise discursiva das relações de poder-saber do discurso politico-educacional de língua estrangeira. Campinas: Mercado de Letras. 
Coracini, Maria José R. Faria. Escrita do Professor, Cidadania e Identidade.

Melman, C. (2002) L'homme sans gravité. Paris: Editions Denoël.

LimA, R. C. P. (2001) "O professor escreve sua história": uma análise discursiva de modos de identificação do sujeito-professor. Dissertação de mestrado em Lingüistica Aplicada pela Unicamp, Instituto de Estudos da Linguagem.

Žž́к, S. (2003) Bem-vindo ao deserto do Real! Trad. Paulo Cezar Castanheira. São Paulo: Biotempo Editorial. 